\title{
Investation of Ectoparasites In Chickens In Village of Kramat District of Bangkalan Regency of Bangkalan
}

\section{Infestasi Ektoparasit Pada Ayam Buras di Desa Kramat Kecamatan Bangkalan Kabupaten Bangkalan}

\author{
${ }^{1)}$ Fania Selfiannisa, ${ }^{2)}$ Suherni Susilowati, ${ }^{3}$ Poedji Hastutiek, ${ }^{3}$ Lucia Tri Suwanti, ${ }^{3)}$ Kusnoto, ${ }^{3)}$ Agus \\ Sunarso \\ ${ }^{1)}$ Student, ${ }^{2)}$ Department of Veterinary Reproduction, ${ }^{3)}$ Department of Veterinary Parasitology. Faculty of \\ Veterinary Medicine, Universitas Airlangga.
}

\begin{abstract}
A study on the infestation of ectoparasites in chicken's raised in Village of Kramat, District of Bangkalan, Regency of Bangkalan was conducted between July to October 2017. A total of 6o chickens were examined based on their sex and region of the chicken's body. Identification was carried out on ectoparasites found identified using permanent mounting methods and scraping. The types of ectoparasites were $M$. gallinae $77 \%, L$. caponis $52 \%$, M. stramineus $15 \%, R$. sanguineus 3\%, G. gallinae 2\%, G. gigas 2\%, and D. gallinae 2\%. Data were analyzed using Chi Square and Correspondence. The results of infestation was higher in males than females, although the difference was not statistically significant ( $\mathrm{P}>0.05)$. Results of analysis of the pattern of investation of ectoparasites in the region that includes in males and females body are $M$. gallinae in the region of the back. L. caponis in the region of the wings. M. stramineus. $R$. sanguineus in the region of the head-neck, G. gigas in the region of belly, G. gallinae in the region of the leg just found in the males body. D. gallinae in the region of the leg just found in the females body.
\end{abstract}

Keywords : Investation, Ectoparasites, Chickens, Pattern, Bangkalan

\section{Pendahuluan}

Ayam buras merupakan salah satu penyumbang kebutuhan gizi asal hewan di Kabupaten Bangkalan. Menurut data Dinas Peternakan Jawa Timur (2017) populasi ayam buras di Kabupaten Bangkalan dari tahun ke tahun semakin meningkat hal ini menunjukkan bahwa banyak masyarakat yang memelihara ayam buras. Pada umumnya sistem pemeliharaan ayam buras masih dipelihara secara tradisional dan tidak dikelola secara baik sehingga terjangkit penyakit terutama yang ditimbulkan oleh parasit, lebih khususnya gangguan ektoparasit (Mokoolang dkk., 2012). Sejauh ini belum pernah dilaporkan mengenai infestasi ektoparasit pada ayam buras di Desa Kramat. Data infestasi ektoparasit dapat digunakan untuk mengantisispasi kemungkinan timbulnya penyakit yang disebabkan oleh penye- baran ektoparasit dan mengendalikan penyebarannya.

Secara umum ektoparasit yang menyerang ayam berasal dari kutu, caplak, dan tungau. Jenisjenis kutu yang banyak menyerang ayam buras di Indonesia adalah Menopon gallinae, Menacanthus stramineus, Cuclogaster heterographus, Goniodes gigas, dan Lipeurus caponis. Jenis caplak yang paling banyak dijumpai di ayam buras adalah Argas persicus dan A. robersi, sedangkan jenis tungau yang banyak menyerang ayam buras di Indonesia adalah Ornythonissus bursa dan Knemidocoptes mutans (Hadi, 2011).

Infestasi ektoparasit merupakan permasalahan yang merugikan. Gigitan ektoparasit menjadi peran yang penting dalam penularan penyakit, dampak dari gigitan ektoparasit yang menginfestasi ayam buras dapat berakibat langsung dan tidak langsung. Dampak secara langsung bisa 
disebabkan karena kehilangan darah dan mengakibatkan anemia, sedangkan dampak tidak langsung mengakibatkan iritasi, dermatosis dan rasa gatal pada kulit (Yadav et al., 2017).

Di Indonesia masih belum ada penelitian mengenai infestasi ektoparasit pada ayam buras. Penelitian ini dilakukan di Desa Kramat Kecamatan Bangkalan Kabupaten Bangkalan dikarenakan secara geografis Desa Kramat terletak di pinggiran sehingga masyarakatnya harus mandiri dalam pemenuhan kebutuhan sehari-hari. Beternak ayam buras sangat membantu masyarakat Desa Kramat karena mudah pemeliharaannya, tidak memerlukan biaya tinggi, dan mudah dijual.

\section{Metode Penelitian}

Sampel yang digunakan dalam penelitian ini adalah 30 ekor ayam buras jantan dan 30 ekor ayam buras betina di Desa Kramat. Bahan yang digunakan $\mathrm{KOH} 10 \%$, Alkohol (30\%, 50\%, 70\%, 95\%, 96\%), xylol, Canada balsam. Alat yang digunakan adalah pot spesimen, optilab, obyek glass, cover glass, mikroskop. Metode yang digunakan adalah permanen mounting tanpa pewarnaan.

Data yang diperoleh kemudian disajikan secara deskriptif. Mengetahui adanya perbedaan infestasi ektoparasit antara ayam buras jantan dan betina dilakukan dengan analisis statistik $C h i$ Square, serta analisis statistik Correspondence untuk mengetahui pola infestasi ektoparasit pada ayam buras jantan dan betina. Analisis statistik dilakukan menggunakan program SPSS (Statistical Product and Service Solution) for Windows rel. 23.

\section{Hasil Dan Pembahasan Identifikasi Ektoparasit}

Hasil identifikasi ektoparasit yang menginfestasi ayam buras di Desa Kramat, Kecamatan Bangkalan, Kabupaten Bangkalan adalah $M$. gallinae $77 \%$, L. caponis $52 \%$, M. stramineus $15 \%$, caplak $R$. sanguineus 3\%, kutu G. gallinae 2\%, G. gigas $2 \%$ dan caplak D. gallinae $2 \%$.
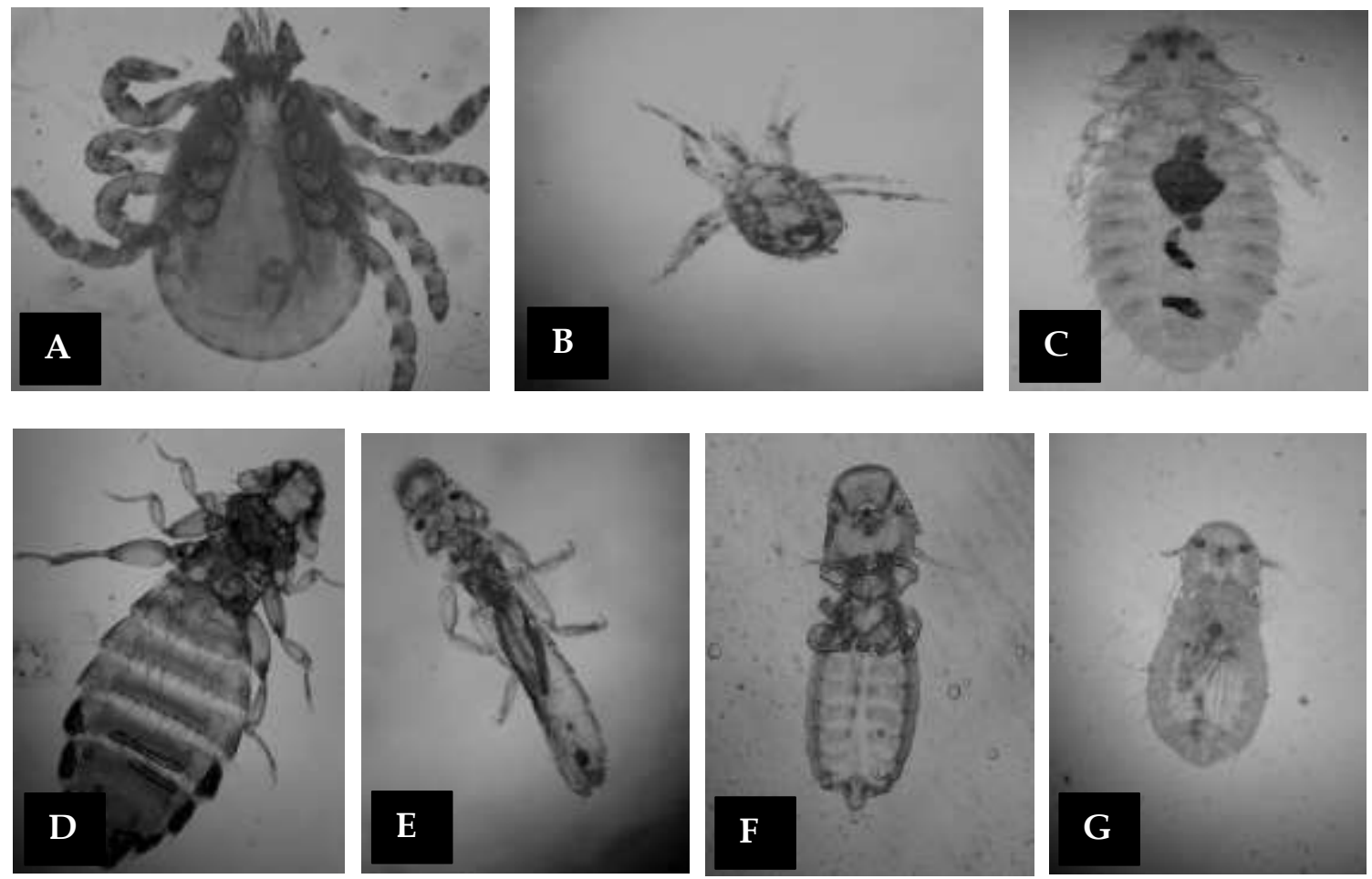

Gambar 1. Jenis Ektoparasit. A. R. sanguineus, B. D. gallinae, C. M. gallinae, D. M. stramineus, E. L. caponis, F. G. gigas, G. G. gallinae 
$R$. sanguineus memiliki ciri capitulum yang berbentuk hexagonal menyatu dengan badan, palpus, chelicera dan hipostom. D. gallinae memiliki 4 pasang kaki, terdapat hypostome sedikit menonjol melewati tepi tubuhnya, dan pada bagian anterior memiliki sepasang chelicera panjang. M. gallinae pada segmen thorax serta abdomen hanya memiliki satu rambut dorsal. $M$. stramineus pada segmen abdominal atau thorax mempunyai dua baris rambut dorsal. L. caponis memiliki ciri khas tubuh panjang, kepala kecil dan menonjol setelah antenna. G. gigas memiliki ciri kepala yang besar. G. gallinae memiliki ciri kepala yang mebulat, kutu terpendek dan bewarna kuning (Soulsby, 1986).

Hasil ini tidak jauh berbeda dengan penelitian di Iran oleh Ebrahimi et al., (2016) menunjukkan jenis ektoparasit yang menginfestasi ayam buras jantan adalah kutu M. gallinae, M. stramineus, L. caponis, dan D. gallinae. Hal ini mungkin disebabkan karena faktor kondisi iklim tropis, kelembaban, dan manajemen kandang yang tidak jauh berbeda dengan di Indonesia.

\section{Infestasi ektoparasit pada ayam buras jantan dan betina}

Ektoparasit dikoleksi dari beberapa peternakan rakyat di Desa Kramat, Kecamatan Bangkalan, Kabupaten Bangkalan sebanyak 30 ekor ayam buras jantan dan 30 ekor ayam buras betina. Ayam buras jantan yang terinfestasi sebanyak 25 ekor dan ayam buras betina yang terinfestasi sebanyak 24 ekor. Hasil tersebut menunjukan arti bahwa tidak terdapat perbedaan infestasi ektoparasit pada ayam buras jantan dan betina ( $>0.05)$.

Tabel 1. Hasil Analisis Chi Square Perbedaan Infestasi Ektoparasit Antara Ayam Buras Jantan dan Betina

\begin{tabular}{ccccc}
\hline Ayam & Positif & Negatif & Total & $\begin{array}{c}\text { Nilai } \\
\text { P }\end{array}$ \\
\hline Jantan & $\begin{array}{c}25 \\
(83.3 \%)\end{array}$ & $\begin{array}{c}5 \\
(16.7 \%)\end{array}$ & 30 & \\
Betina & $\begin{array}{c}24 \\
(80 \%)\end{array}$ & $\begin{array}{c}6 \\
(20 \%)\end{array}$ & 30 & \\
\hline
\end{tabular}

Penelitian ini dilakukan dengan jumlah sampel hanya 6o ekor ayam buras. Penelitian serupa dengan jumlah sampel ayam yang lebih besar, yaitu pada ayam jantan 149 ekor dan pada ayam betina 241 ekor, menunjukkan bahwa tidak terdapat perbedaan infestasi ektoprasit antara ayam jantan dan ayam betina (Tamiru et al., 2014)..

Pola infestasi ektoparasit pada ayam buras jantan dan betina

Tabel 2. Infestasi Ektoparasit pada Ayam Buras

\begin{tabular}{cllc}
\hline Ayam & Regio & Ektoparasit & $\begin{array}{c}\text { Jumlah } \\
\text { (Ekor) }\end{array}$ \\
\hline \multirow{6}{*}{ Kepala-Leher } & R. sanguineus & 2 \\
& Punggung & & 2 \\
& Abdomen & & 3 \\
& Kepala-Leher & M. gallinae & 18 \\
& Punggung & & 20 \\
& Sayap & & 3 \\
Abdomen & & 11 \\
Kaki & & 10 \\
& Ekor & & 7 \\
Kepala-Leher & L. caponis & 14 \\
& Punggung & & 2 \\
& Sayap & & 9 \\
& Ekor & G. gigas & 5 \\
& Abdomen & 1 \\
& Punggung & G. gallinae & 1 \\
Kaki & D. gallinae & 1 \\
& Punggung & M. stramineus & 1 \\
Abdomen & & 1 \\
Kepala-Leher & M. gallinae & 14 \\
Punggung & & 14 \\
Sayap & & 8 \\
Abdomen & & 10 \\
Kaki & & 3 \\
Ekor & & 7 \\
Kepala-Leher & L. caponis & 7 \\
Punggung & & 1 \\
Sayap & & 6 \\
Ekor & & 2 \\
\hline & &
\end{tabular}

Caplak $R$. sanguineus yang menginfestasi ayam jantan dalam penelitian ini kemungkinan karena pola pemeliharaan ayam yang tidak memperhatikan sanitasi lingkungan yang baik dikarenakan kandang ayam berdekatan dengan kandang sapi sehingga caplak yang ditemukan bisa berasal dari sapi yang terinfestasi caplak dekat kandang ayam. Selain itu, ayam jantan dibiarkan bebas dan lebih aktif sehingga memungkinkan terjadi infestasi silang. Menurut 
Hastutiek dkk., (2014) caplak merupakan parasit ternak yang dapat menimbulkan kerugian ekonomi yang serius diakibatkan turunnya kondisi tubuh, anemia, dan dapat menyebabkan kematian.

Kutu M. gallinae tersebar di seluruh regio tubuh ayam jantan dan ayam betina. Pola infestasi dari kutu tersebut menunjukkan kedekatan pada regio punggung. Hasil yang sama juga diketahui pada penelitian yang dilakukan Olantuji (2016) bahwa kutu tersebut tersebar pada regio tubuh ayam terutama regio punggung. Hasil penelitian ini, kutu M. gallinae ditemukan dalam jumlah yang besar pada ayam buras jantan dan betina dan menyebar hampir merata dapat dikaitkan ketidakspesifikannya pada bagian tubuh inang yang mengindikasikan bahwa kutu ini mampu berkembang baik pada regio tubuh inang.

Pada saat penelitian ayam buras betina ditemukan D. gallinae pada siang hari. Hasil analisis menunjukkan bahwa pola infestasi tersebut menunjukkan keeratan dengan regio kaki. Sama dengan hasil penelitian yang dilakukan oleh Hobbenaghi et al., (2012) D. gallinae ditemukan pada regio kaki di siang hari. D. gallinae terkadang berada di celah-celah atau dinding dan atap. Sifat D.gallinae adalah nocturnal yang aktif saat malam hari, merayap pada kaki ayam, menggigit kulit ayam dan menghisap darah. Infestasi yang hebat dapat mempengaruhi produktivitas telur dan kematian karena kehilangan darah (Flochlay et al., 2017). D. gallinae dapat menularkan ke manusia yang mengakibatkan lesi-lesi pada kulit hal ini mengindikasikan bahwa D. gallinae bersifat zoonosis (Bhat et al., 2014).

\section{Kesimpulan}

Jenis ektoparasit yang menginfestasi ayam buras di beberapa peternakan rakyat Desa Kramat, Kecamatan Bangkalan, Kabupaten Bangkalan ditemukan $M$. gallinae, $L$. caponis, $M$. stramineus, $R$. sanguineus, G. gallinae, dan $G$. gigas dan D. gallinae. Berdasarkan analisis statistik Chi square diketahui bahwa tidak terdapat perbedaan infestasi ektoparasit pada ayam buras jantan dengan ayam buras betina. Berdasarkan analisis statistik Correspondence pola infestasi ektoparasit pada regio tubuh ayam buras jantan dan betina menunjukkan kutu $M$. gallinae pada regio punggung, L. caponis pada regio kepala-leher dan sayap, dan $M$. stramineus pada regio abdomen. Pola infestasi caplak $R$. sanguineus pada regio kepala-leher, kutu G. gigas pada regio abdomen, dan G. gallinae pada regio kaki hanya ditemukan pada ayam buras jantan.

\section{Daftar Pustaka}

Bala, A.Y., S.A. Anka., A. Waziri., and H. Shehu. 2011. Preliminary Survey of Ectoparasites Infesting Chickens (Gallus domesticus) in Four Areas of Sokoto Metropolis. Nigerian J of Basic and Applied Sci. 19(2): 173-180.

Bhat, S.A., M.Y. Wani., J.K. Khojuria., R.Katoch., and K. Dhama. 2014. A Rare Report of Ectoparasites in Backyard Poultry in Jammu Region : Prevalence Study and Economic Importance. Asian J. Anim. Vet. Adv. 9(11):727-731

Ebrahimi., M. Samiei., K. Anousheh., D.R. Jalali. 2016. Identification of ectoparasites in indigenous poultry in southern areas of West Azerbaijan, Iran: A study on the prevalence and importance of these parasites. Ahvaz. Archives of Razi Institute 71(4): $253-258$

Flochlay, A.S., E. Thomas., and O. Sparagano. 2017. Poultry red mite (Dermanyssus gallinae) infestation: a broad impact parasitological disease that still remains a significant challenge for the egg-laying industry in Europe. Parasites \& Vectors . 10:35

Hadi, U. P. 2011. Bioekologi Berbagai Jenis Serangga Penganggu pada Hewan Ternak di Indonesia dan Pengendaliaanya. Bagian Parasitologi dan Entomologi Kesehatan. Fakultas Kedokteran Hewan Institut Pertanian Bogor. 10-11

Hastutiek, P., R. Sasmita., A. Sunarso., M. Yunus. 2014. Ilmu Penyakit Arthropoda Veteriner. Cetakan I. Pusat Penerbitan dan Percetakan UNAIR. 35 - 49 